\section{Original} Article

Access this article online Website:

http://ajobe.journals.ac.za/ DOI:

http://dx.doi.org/10.15249/6-1-3 Quick Response Code:

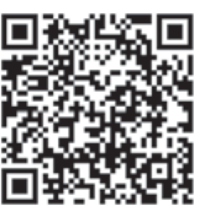

Address for correspondence: Mr. Chukwunonye O. Emenalo, Department of Accounting, Finance, and Economics, Lagos Business School, Pan-African University, Km 22, Lekki-Epe Expressway, Ajah, Lagos, Nigeria. E-mail: cemenalo@lbs.edu.ng, chuks.emenalo@gmail.com

\title{
Corporate governance systems as dynamic institutions: Towards a dynamic model of corporate governance systems
}

\section{Chukwunonye O. Emenalo}

Department of Accounting, Finance, and Economics, Lagos Business School, Pan-African University, Km 22, Lekki-Epe Expressway, Ajah, Lagos, Nigeria

\section{ABSTRACT}

Taking note of the evidence in extant literature that corporate governance systems are designed to incentivise, monitor, and guide agents to achieve firm mission, this paper develops a dynamic model of corporate governance systems that views these systems as artificial realities (Simon 1996) in general, and institutions in particular. The paper suggests that viewing these systems as institutions has theoretical and practical implications for the study and design of these systems, and illuminates how the process of double hermeneutic may explain the link between corporate governance research and policy recommendations to date and the US sub-prime crisis of 2007 onwards.

Key words: Agency theory, Artificial realities, Corporate governance systems, Institutions, institutional theory, Process of double hermeneutic, Performativity

\section{INTRODUCTION}

In recent times, there have been calls to develop models of corporate governance systems that take into account a balanced view of human nature and behaviour (Ghoshal 2005) and that can be applied globally to allow for the different contexts of firms (Filatotchev and Boyd 2009; Gomez-Mejia, Wiseman, and Dykes 2005; Lubatkin, Lane, Collin, and Very 2005; Lubatkin, Lane, Collin, and Very 2007). It is also widely acknowledged that the model most often used in corporate governance research and policy recommendations is the Jensen-Meckling $(\mathrm{J} / \mathrm{M})$ model of agency (Dalton, Daily, Ellstrand, and Johnson 1998; Filatotchev and Boyd 2009; Shleifer and Vishny 1997).

The US sub-prime mortgage crisis of 2007 onwards and consequent economic crisis that started a year later have led to a deep examination of the causes of the crises and how such crises can be prevented in the future. It has also been suggested that a possible cause of the sub-prime mortgage crisis is the failure of existing corporate governance systems. Research (Davis 2005; Fligstein 2002; Ghoshal 2005; Lazonick and O'Sullivan 2000) has shown how, over time, through corporate governance research and policy recommendations, corporate governance systems are being designed and evaluated by the guiding principle of Shareholder Value Maximisation (SVM), and how agents of firms, especially in Anglo-Saxon countries, have accepted that their goal is to maximise their principals' financial returns in accordance with the assumptions of the $\mathrm{J} / \mathrm{M}$ model of agency.

Bearing the above discussion in mind, this paper aims to contribute towards the development of a dynamic model of corporate governance systems that takes into account the existing evidence in the literature. This dynamic model views corporate governance systems as artificial realities (Simon 1996) in general, and institutions in particular, and can throw more light on the antecedents of immediate behavioural outcomes like opportunistic or stewardship behaviours of agents. Furthermore, the paper suggests that once corporate governance systems are viewed as artificial realities in general and institutions in particular, the process of double hermeneutic, synonymous in this paper with the processes of performativity or self-fulfilling prophecy, may explain the link between corporate governance research and 
policy recommendations to date and the US sub-prime crisis of 2007 onwards.

The paper is organised as follows. First, the paper defines and discusses the phenomenon of corporate governance systems in a brief literature review. Then it states some problems and limitations of the prevailing corporate governance model, that is, the J/M model of agency. Second, the paper presents arguments based on the existing empirical evidence on corporate governance systems to show why corporate governance systems are better viewed as artificial realities in general and institutions in particular. Then the paper discusses the dynamic model of corporate governance systems developed here and explains its features. Third, the paper discusses the contributions of the dynamic model's features to corporate governance literature and concludes.

\section{LITERATURE REVIEW: THE PHENOMENON OF CORPORATE GOVERNANCE SYSTEMS}

In this paper, a firm is viewed as a for-profit organisation made up of many members, including the top management team (TMT) and the board of directors, that is in a dyadic relationship with its environment (Scott and Davis 2007:117). The paper assumes that the board of directors includes those who represent the principals of the firm, and that the principals of the firm have the ultimate right to decide and approve the firm's goals, values, commitments, and identity, specifically approving the firm's mission. This is the typical situation found in many incorporated firms and where it is assumed that there is separation of ownership and control. In this way, the ideas presented here can be compared to previous literature.

Following Hambrick, Werder, and Zajac (2008: 381), the paper defines corporate governance systems as "the formal structures, informal structures, and processes that exist in oversight roles and responsibilities in the corporate context." Similarly to Hambrick et al. (2008), Licht, Goldschmidt, and Schwartz (2005:234) define corporate governance systems as "the framework that defines the division of wealth and power in the corporation. Legal rules that shape this division are scattered in various parts of countries' laws, including specific corporate laws, general commercial codes, bankruptcy codes, financial institution regulations, etc." Corporate governance systems are usually studied within an interdisciplinary field of study called corporate governance, which is concerned not only with the study of corporate governance systems but also with the principles that guide their design and selection, particularly antecedents of corporate governance systems, and consequences of corporate governance systems for the survival of a firm and fulfilment of a firm's mission.
The J/M model of agency, called agency theory in most circles, although there seems to be many types of agency theory (see Eisenhardt 1989, Holmstrom 2005, Jensen 1983, Levinthal 1988), is the prevalent model used in corporate governance systems research and policy recommendations (Jensen and Meckling 1976; Shleifer and Vishny 1997). It is a model that states that in a situation of separation of ownership and control, that is, where the principals are not the agents managing the firm, there is a high likelihood that there will be a conflict between the goals of principals and agents, and that this conflict can produce agency problems that reduce the economic efficiency of the firm and, consequently, reduce the firm's financial performance.

In the $\mathrm{J} / \mathrm{M}$ model, the principals are assumed to be those that possess the firm's shares. However, it is also known that the shareholders of a firm include short-term profit seekers and speculators. Consequently, this paper refers to principals of a firm as those who have the ultimate decision rights as to the goals, values, commitments, and identity of the firm, and not to everyone that has shares in a firm. In the J/M model of agency, principals and agents are assumed to be Resourceful-Evaluative-Maximisers (REM) of their utilities. A principal's utility is assumed to be the financial return on investment in the firm, while an agent's utility consists of financial compensation, perks, non-pecuniary compensations, or monetary (dollar) equivalents.

Since agents are assumed to want to maximise their own utility, if agents' utility is not the same as that of the principals, there is conflict, and if agents are not monitored and/or financially incentivised to align their utility with that of principals, agents may appropriate the financial return of principals in an effort to maximise their own utility. Therefore, principals have to monitor, design, and implement financial incentives to reduce agency problems. All this, the J/M model predicts, would lead to higher financial performance in the presence of efficient markets. These monitoring and incentivising systems make up the corporate governance systems installed by the principals. The implicit assumption in the J/M model is that, ideally, corporate governance systems improve the economic efficiency of the firm, thereby generating higher financial performance for the principals.

Many corporate governance researchers (see Dalton, Daily, Certo, and Roengpitya 2003; Dalton et al. 1998; and Tosi, Werner, Katz, and Gomez-Mejia 2000 for a review of related literature) have tried to apply the J/M model of agency in order to explain corporate governance systems, their antecedents, and their consequences. The J/M model of agency suggested some systems that were expected to reduce the opportunism of agents, align the goals of principals and agents, and consequently increase the market value of firms. These systems incorporate, amongst others, board 
independence, separation of the roles of Chief Executive Officer (CEO) and Board Chairmanship, and aligning TMT financial compensation to stock performance of firms.

However, recent meta-analyses have shown that the relationship between a lower agency problem and higher market value seems not to exist in reality. For example, Dalton et al. (2003) showed through their meta-analysis that the proposed relationship between equity ownership, argued to align utility of agents and principals, and firm performance seems not to exist; Dalton et al. (1998) showed that there is little evidence of a link between governance structure and firm financial performance; Tosi et al. (2000) showed that the link between CEO pay and firm performance is also weak, and suggests that the agent's monetary compensation, which is meant to align the agent's utility with those of the principal, seems not to be associated much with firm market value.

Apart from the meta-analyses, empirical evidence also shows that the incentives suggested in the J/M model, such as stock options, bonuses, and high-powered monetary incentives tied to the market value of the firm, may lead agents to focus on short-term quarterly profits that may benefit shareholders in the short term but may destroy firm market value and, consequently, firms in the long run (Becht, Bolton, and Röell 2003; Dobbin and Jung 2010; Ghoshal 2005; Roberts 2010).

An important idea from the $\mathrm{J} / \mathrm{M}$ model of agency is that agency problems exist and cannot be completely eliminated. Thus, researchers are encouraged to avoid thinking about a perfect world without agency problems and focus on the real world with agency problems. However, the link between agency problems and financial performance of firms has thus far proven elusive, as is evident from the meta-analyses of empirical tests, stated above. This paper suggests that three conclusions can be deduced from this lack of systematic and substantial relationships and associations between agency problems and the market value of firms:

- Scope issues: Was the model applied in the right contexts? The predictions of the J/M model of agency were developed to hold in efficient markets. Hence, efficient markets ensure that lower agency problems would lead to higher economic efficiency and, consequently, higher market value. However, over the years, it seems that corporate governance researchers have lacked diligence in accounting for the possible real-life inefficiency of markets. Hence, without efficient markets, it may be difficult to find a substantial causal link between lower agency problems and higher firm financial performance as developed in the $\mathrm{J} / \mathrm{M}$ model of agency.

- Assumptions about principals' goals: It is possible that corporate governance systems that were suggested and predicted to reduce agency problems by limiting opportunistic acts of agents and aligning agents' goals to assumed principals' goals of maximum market value are not working as the J/M model predicted. This may be because corporate governance systems are not designed by all principals to increase the market value of their firm, and assuming that all principals want to maximise the market value of their firms may not capture well the key antecedents to design of corporate governance systems. Based on empirical evidence, many publicly traded firms have principals that have the ultimate decision rights and, globally, these principals are mainly governments or families and have non-financial goals (Anderson and Reeb 2003; Gomez-Mejia, Haynes, Núñez-Nickel, Jacobson, and Moyano-Fuentes 2007; La Porta, Lopez-de-Silanes, Shleifer, and Vishny 1999). Large-scale secondary database samples may not take these differences in goals into account, and this may account for the lack of a substantial link between lower agency problems and higher market value, as was evident in the meta-analyses.

- Construct validity, empirical measurement, and testing issues: The J/M model states that agency problems are created due to the conflict between the goals of principals and agents. Whilst the J/M model predicts that higher agency problems lead to lower financial performance, as seen in the lower market value of a firm in the presence of efficient markets, researchers (see Dalton et al. 2003; Dalton et al. 1998; and Tosi et al. 2000 for a review of related literature) have only so far examined firms that have used corporate governance systems suggested by the $\mathrm{J} / \mathrm{M}$ model. Instead of measuring agency problems directly, scholars have tested whether these corporate governance systems actually reduced agency problems by looking at the financial performance of the firm, and change in financial performance then becomes a proxy for change in agency problems. However, firms' financial performance, operationalised as their profit and market value, has been empirically observed to be affected by many exogenous and endogenous factors (Demsetz and Villalonga 2001; Gimeno, Folta, Cooper, and Woo 1997) apart from possible links to agency problems. For example, luck is a typical exogenous factor not fully under the control of agents or principals of firms. This paper defines luck as those variables, like customer preferences and government/political economic policies, that affect firm profit and market value, and are under the control of neither agents nor principals. Therefore, the financial performance of the firm is uncertain to agents and principals ex-ante. Uncertainty refers to outcomes whose probability cannot be estimated ex-ante (Knight 2002; Santos and Eisenhardt 2005); the higher the uncertainty, the higher the impact of luck on outcomes.

Therefore, financial performance may be further removed from agency problems than originally thought. The J/M 
model of agency, taking a financial economic view of the firm (Lane, Cannella Jr, and Lubatkin 1999; Lubatkin 2005), assumes that lower agency problems would lead to higher firm economic efficiency, reflected in higher market value. From the discussions above, the empirical evidence so far seems not to support this link between lower agency problems and higher market value. This paper suggests that there is a need to uncouple the link between agency problems and profit/market value and do research with performance outcomes that are more within the control of the principals/agents. This does not mean that principals cannot have the goal of financial performance. The foregoing discussion only highlights that it is important to note that financial performance is completely under the control of neither principals nor agents.

Hence, it appears that the causal link between lower agency problems and higher market value as predicted by the $\mathrm{J} / \mathrm{M}$ model of agency may not exist in reality, and the J/M model of agency, in its current form, may be inapplicable to the study of real world corporate governance systems, antecedents, and outcomes.

Due to the abovementioned problems and limitations of the $\mathrm{J} / \mathrm{M}$ model of agency and other related problems and limitations highlighted in the literature (Dalton, Hitt, Certo, and Dalton 2007; Ghoshal 2005; Lubatkin 2005), the J/M model of agency seems in need of further development by improving its underlying assumptions and reasoning. In addition, an improved model, should, ideally, help principals improve their corporate governance systems, achieve their mission, and facilitate policy-making. Consequently, the current paper illustrates below a dynamic model of corporate governance systems that attempts to build on the ideas of agency problems, incentives, and managerial monitoring present in the J/M model of agency, but enriching them based on the nature of corporate governance systems as institutions, to be argued below.

\section{THE DEVELOPMENT OF THE DYNAMIC MODEL OF CORPORATE GOVERNANCE SYSTEMS}

This paper here presents some ontological points that clarify how the dynamic model helps explain how existing corporate governance systems may be better understood. Corporate governance systems, like many phenomena studied in social science in general and management in particular, are artificial (Simon 1996). Artificial realities are phenomena designed by humans for a purpose, and are, in most dimensions, different from natural realities, specifically those studied in natural sciences. In addition, corporate governance systems, designed as monitoring, incentive, and strategic guiding systems can be viewed as institutions that are a subset of artificial realities, with institutions being defined as proposed by North (North 1990; North 2005).
Nature of corporate governance systems

It is important to note that social science phenomena, particularly human designs, collective action problems, and social groups, are not natural realities like gravity or the solar system, but artificial realities, mostly designed by humans and changeable by humans. Artificial reality is different from natural reality, with the latter's origin, nature, and guiding principles being neither designed nor changeable by humans. Simon (1996:5) clearly outlines four differences between artificial and natural realities: artificial realities are knowingly or unknowingly synthesised by humans; they are very similar to natural realities but lack aspects of the reality of natural realities; they are characterised by functions, adaptation, and goals; and they are discussed in terms of both imperatives and descriptives.

Knowing that artificial realities are designed and changeable by human beings can help explain how the Process of Double Hermeneutic (PDH) links knowledge developed by social scientists to their audiences' decisions and designs. $\mathrm{PDH}$ can be broadly defined as the process by which social science knowledge and recommendations affect social life and practice, whether intentionally or unintentionally. Giddens explains the PDH as, "a mutual interpretative interplay between social science and those whose activities compose its subject matter-a 'double hermeneutic'" (Giddens 1986: xxxiii). What the PDH implies is that the knowledge developed by social scientists can become part of the knowledge that humans use in designing their artificial realities. For example, when principals and agents are negotiating corporate governance systems, they use the available knowledge, including the knowledge developed by social scientists and management researchers, about corporate governance systems; and, therefore, social scientists need to be careful with the knowledge they develop and disseminate (Ferraro, Pfeffer, and Sutton 2009).

There is growing evidence that social science theories, especially the most widespread and applied in social and economic policies, that is, neoclassical and financial economics, affect human designs according to their assumptions of human nature, the theoretical models developed, and recommendations derived from the theories (Ferraro, Pfeffer, and Sutton 2005; Ferraro et al. 2009; Ghoshal and Moran 1996b; Ghoshal 2005; Mackenzie 2008). Keynes spoke about the PDH many years ago and said that "the ideas of economists and political philosophers, both when they are right and when they are wrong, are more powerful than is commonly understood... But, soon or late, it is ideas, not vested interests, which are dangerous for good or evil" (Keynes 1964: 383-384).

This paper suggests that the PDH may explain how corporate governance research and recommendations to date may have contributed to the US sub-prime crisis of 2007 onwards. Through the PDH, existing corporate 
governance research and recommendations may have led to the design of corporate governance systems that encouraged actions by providing the wrong incentives (Dobbin and Jung 2010; Roberts 2010). To illustrate how the PDH may show the link between corporate governance recommendations and the US sub-prime crisis, one needs to consider the three mechanisms identified by Ferraro et al. (2005) through which the PDH affects human designs: institutional design, social norms, and language. PDH may link corporate governance recommendations to the crisis through:

- Institutional design as embodied in the design of corporate governance systems;

- Social norms and decision rules consistent with the mission of principals and which become embedded in corporate governance systems negotiated between principals and agents; and

- Language that includes the use of concepts like agency costs, self-serving managers, and SVM, which are used in the communication between principals and agents within the firm and in communication in the organisational field in which firm is immersed; this language can affect the goals and incentives of principals and agents.

These three mechanisms are reflected in the following plausible account that illustrates how the PDH may link corporate governance recommendations to date to the crisis. Based on extant literature, principals and agents can focus on money and financial goals only or have broader goals and values. However, the financial economic view of the firm, as reflected in J/M model of agency (Lane et al. 1999), advances that principals and agents are and should only be interested in financial goals, and that agents are always opportunistic and would search for ways to maximise their material utility if not prevented with controls. Principals and agents come to accept the financial economic view, leading to a so-called SVM concept of control or SVM institutional logic (Fligstein 2002; Holmstrom 2005).

Principals focus on financial goals only and ask agents to do the same by designing corporate governance systems to ensure a focus on financial goals. Principals also emphasise, using the corporate governance systems negotiated between principals and agents, that they assume that agents are always opportunistic, cannot be trusted, and need constant monitoring and control. Agents then focus mainly on financial goals and, in addition, convinced that they are expected to be opportunistic, also look for ways to enrich themselves at the expense of their principals and society at large, taking excessive risks without considering the effects of these risks on other persons affected by the activities of their firms.

Hence, one can see how a self-reinforcing cycle is developed as principals use corporate governance systems to ensure that agents focus on financial goals and to emphasise that agents cannot be trusted. Agents become more opportunistic as they are encouraged and given incentives that make them even more opportunistic. Then we get the situation that led to the US sub-prime mortgage crisis of 2007. An analysis in The Economist captures the above account well (Economist 2009) and basically states how financial firms' managers, moved by the incentives to maximise shareholder value through maximising short-term profits and quarterly results took excessive risks in sub-prime mortgage lending, seemingly without thinking much about the long-term consequences of such behaviour for their firm and other stakeholders of the firm.

Bearing in mind the effects of the PDH and the evidence presented so far in the literature that agents may be either opportunists or stewards (Davis, Schoorman, and Donaldson 1997), the dynamic model presented here assumes that agents have a disposition to be opportunistic and also to be docile (Simon 1991). Moreover, the values, norms, and incentives of the firm's agents and principals that guided the design of the corporate governance systems, can foster either opportunistic or stewardship behaviour in agents. The dynamic model presented below would not ex-ante assume that agents and principals are always opportunistic, since this assumption may have negative effects working through the PDH and, in addition, does not align with observed behaviour of all agents. The idea of the possible negative effect of assuming that all agents are always opportunistic ex-ante is discussed well by Ghoshal and Moran (1996a).

In addition, this paper assumes ex-ante that principals and agents would want and sometimes need to follow the stakeholder approach, which includes following normative principles like that of the Golden Rule, which states that one should treat others as one expects to be treated by others (Grisez, Boyle, and Finnis 1987; Melé 2009a; Melé 2009b; Melé 2012) if one wants to be seen as morally responsible, socially appropriate, respectful to other persons, and hence most likely avoid litigation. However, the current paper does not assume that agents and principals may not carry out socially harmful activities. This is an empirical issue. It only assumes that agents and principals may exhibit either opportunistic or stewardship behaviours.

\section{Corporate governance systems as institutions}

If corporate governance systems are designed to monitor, incentivise, and strategically guide agents to fulfil the mission of the firm as desired by principals, thereby possibly reducing agency problems, this paper argues that corporate governance systems be viewed conceptually as evolving institutions, that is, institutions as defined by North (1990). Institutions, as defined by North (1990:3), are "the rules of the game in a society or, more formally, are the humanly devised constraints that shape human interaction. In consequence they structure incentives in human exchange, 
whether political, social, or economic." From the definition and discussions of institutions by North (1990), one can view institutions simply as humanly devised constraints. Hence, institutions are a sub-set of artificial realities that guide human choices, interaction, and behaviour as regards political, social, and economic activities.

North identifies the way we greet others, drive automobiles (whether on the left or right side of the road), and bury the dead as guided by institutions (North 1990: 3-4) and thus institutions are involved in human interaction at practically every level of society and social analysis. North (1990) also emphasises the importance of analytically separating the institutions-the rules of the game-from the actors-the players in the game-that use the institutions to guide their interaction, if one wants to better understand institutions. Therefore, institutions are analytically distinct from the actors that create and use them, even though, in reality, institutions are constantly being created and modified by the actors. Institutions can be coercive, normative, and/or internally motivating as internalised and taken-for-granted cognitive logics of action.

Since corporate governance systems fit this definition of institutions as humanly devised constraints and guides for decision making, one can view corporate governance systems as institutions. This implies that institutions exist at the macro level in the firm's organisational field, but also at the micro level within the firm in order to guide human interaction and the pursuit of the firm's mission. Corporate governance systems can include formal aspects such as strategic planning rules, compensation rules, resource allocation rules, and informal aspects such as the dos and don'ts in the firm that are consistent with the values, firm character, and commitments desired by the firm's principals. In addition, it is assumed that these institutions are established with enforcement mechanisms so that they are more effective and affect behaviour in the desired way. A classification of corporate governance system components into formal and informal institutions is given in Table 1 .

\section{The dynamic model of corporate governance systems}

The dynamic model developed here attempts to respect the nature of corporate governance systems as discussed above, and consequently may better explain the antecedents and consequences of corporate governance systems. In addition, because the dynamic model of corporate governance systems presented below respects the nature of corporate governance systems as institutions, it may explain the antecedents and consequences of different corporate governance systems in different firms and in different locations around the world. The dynamic model is presented in Figure 1.

The dynamic model has two levels: Environment and firm level. The environment level can be viewed as the
Table 1: Classification of corporate governance system components

\begin{tabular}{|c|c|c|}
\hline & Formal institutions & Informal institutions \\
\hline $\begin{array}{l}\text { Corporate } \\
\text { governance } \\
\text { system } \\
\text { components }\end{array}$ & $\begin{array}{l}\text { Examples include } \\
\text { strategic planning rules, } \\
\text { resource allocation rules, } \\
\text { board composition rules } \\
\text { (i.e. proportion of insiders } \\
\text { and outsiders; proportion } \\
\text { of independents, number } \\
\text { of outside directors), } \\
\text { board structure rules } \\
\text { (CEO duality and number } \\
\text { of committees), formal } \\
\text { compensation contract } \\
\text { rules for agents with } \\
\text { stipulations of rewards } \\
\text { and punishments, etc }\end{array}$ & $\begin{array}{l}\text { Examples include the } \\
\text { norms of behaviour, } \\
\text { the dos and don'ts, } \\
\text { consistent with } \\
\text { the values and } \\
\text { commitments that are } \\
\text { part of the mission of } \\
\text { the firm and that guide } \\
\text { decision making by the } \\
\text { principals and agents }\end{array}$ \\
\hline
\end{tabular}

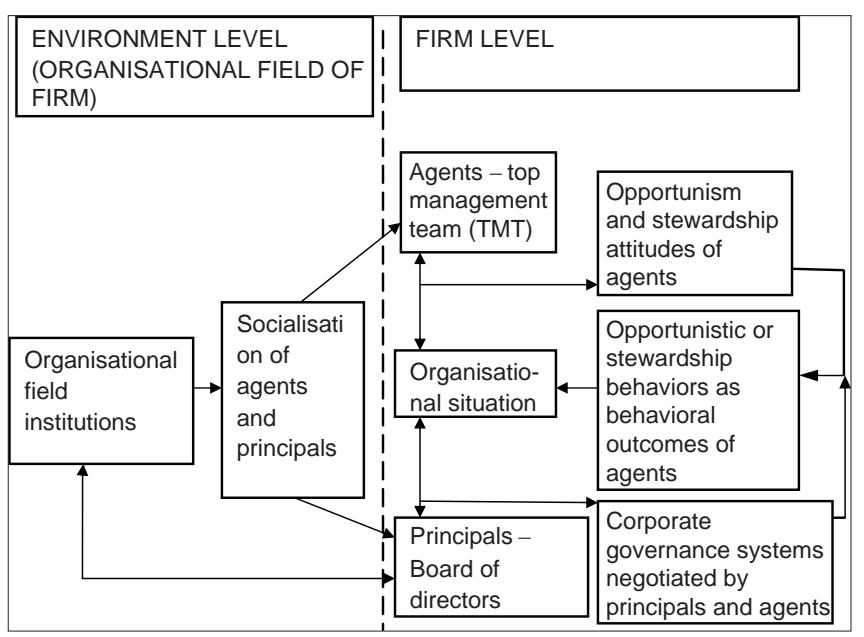

Figure 1: A dynamic model of corporate governance systems

organisational field in which the firm is immersed. The model is designed to cover corporate governance systems around the world in which the TMT or the executive board of a firm correspond to agents, and the board of directors or supervisory board represents principals in order to accommodate unitary and two-tier board structures (Tricker 2009). The dynamic model is closely related to the framework of Lubatkin et al. (2007), to which the study integrated insights from the agency and resource dependency model proposed by Hillman and Dalziel (2003) and stewardship theory (Davis et al. 1997).

In the dynamic model of corporate governance systems presented here, the concept of mission is used to substitute the goals of principals. The negotiated corporate governance systems are like a second stage in each firm level cycle. The first stage is always the mission adopted by the principals to pursue. After adopting a satisfactory mission, corporate governance systems are negotiated to ensure that agents work to achieve the mission. This paper argues that a mission is a broad concept and can capture more than goals. Mission encompasses the desired goals, 
values, commitments, identity, and guiding principles for decision-making of the firm. Following Selznick (1984: 61-89), this paper assumes that, since principals want to achieve a mission-for example, offer a particular product to consumers, and as a consequence generate income for other wants and also needs-and also need to bring in human and financial capital to achieve this mission, the firm becomes a human community pursuing a collective mission. The human community may then value the firm for itself as it fulfils social and psychological functions.

Mission encompasses economic, sociological, and psychological considerations by principals of the firm and answers the questions: What shall the firm do? (for example, What products/services of value should the firm offer to consumers?); and What shall the firm be? (for example, What should the firm be known for; what are its distinctive identity and competence?). The mission of the firm embodies the goals of principals, the goals of their human and capital providers, as well as the values, commitments, and guiding principles that make up the distinctive identity and competence of the firm. Therefore, research into the composition of the principals, specifically those who hold the ultimate decision rights in a firm, will help determine the key aspects of the mission of the firm, and therefore constitutes the first stage when carrying out empirical research using the dynamic model presented above.

In addition, the concept of mission is also dynamic and may not need to be very specific at every point in time, allowing flexibility in adapting to future opportunities and threats in changing organisational field conditions. A firm is considered to be a learning organisation in which the interaction and negotiations within the firm enable principals and agents to modify aspects of the firm's mission and, consequently, the negotiated corporate governance systems as new information and experiences come in and firms try to adapt to changing conditions in the firm's organisational field. Therefore, strategies can emerge unforeseen ex-ante and then be incorporated as intended strategies (Mintzberg and Waters 1985) in the firm's mission. The different aspects of the mission help to evaluate the effectiveness of the negotiated corporate governance system.

Operationalising a mission is a difficult task, but it can be simplified by using a dichotomy of financial and non-financial goals as a first level of simplification. The financial goal captures the economic dimension, while the non-financial goals capture the social and psychological benefits of the firm to the principals, agents, the firm's members, and other stakeholders of the firm (what Gómez-Mejía et al. (2007) call "socioemotional wealth"). Other aspects of the firm's mission can be captured under typical performance measures that are relatively under the control of principals and the agents, such as research and development expenditures, the cost and quality of production, advertising expenditures, customer satisfaction indices, the firm's members' work satisfaction index, and administrative costs. However, one can still use profit and market value performance measures, when available, as proxies for achievement of financial goals. In addition, these profit and market value measures are not completely under the control of either the principals or the agents, and so may not capture well enough the link between agents' behavioural outcomes, decisions, and performance measures. If the stock market is not efficient in the sense of capturing the future and present intrinsic and fundamental value of the decisions of the agents (Summers 1985), then the stock market value of a firm may not help us capture the effectiveness of that firm's adopted corporate governance systems.

Human interaction at the organisational field level lead to the development of institutions to guide political, social, and economic activities. In the model above, principals have the internal and external roles as recognised in the literature (Finkelstein, Cannella, and Hambrick 2009; Hambrick et al. 2008). As part of the external role, institutions are negotiated by principals and other organisational stakeholders in the firm's organisational field to ensure accountability. For example, the principals, a government agency like the Securities and Exchange Commission (SEC), and other organisational stakeholders can negotiate formal institutions to protect the interests of all investors.

Agents and principals are socialised in this organisational field before coming into the firm's boundaries. Therefore, the model reveals that the corporate governance systems that will be negotiated by principals and agents in the organisational situation within the firm will be affected by the institutions already in existence at the organisational field level. Socialisation is assumed to lead to agents and principals acquiring human and social capital that they bring to the organisational situation within the firm (Hillman and Dalziel 2003).

In the organisational situation, coevolutionary sense-making is assumed to take place between principals and agents (Lubatkin et al. 2007), where principals perform their functions of monitoring and providing incentives, resources, and strategic guidance to agents (Finkelstein et al. 2009; Hillman and Dalziel 2003), and agents perform their function of providing information about firm operations to principals, making strategy suggestions to principals, and implementing the firm's mission. Corporate governance systems are then negotiated in this organisational situation, and feedback from behavioural outcomes of agents is captured in the organisational situation. These corporate governance systems are made up of formal and informal aspects, and their corresponding enforcement mechanisms-coercive processes for formal aspects and normative processes for informal 
aspects. These corporate governance systems condition and guide agents' choices within the firm, and are aimed at helping agents achieve the mission of the firm; they are also expected to reduce agency problems. Agents are consequently assumed to follow institutions based on the logic of incentives and logic of appropriateness (Thornton and Ocasio 2008: 106).

An opportunistic attitude as used in the dynamic model implies taking decisions without considering their effects on others, and thinking only about one's own material benefits. A stewardship attitude implies taking decisions while considering their effects on others and sometimes acting solely for the sake of the others, even at one's own material and financial expense. This implies that opportunistic and stewardship attitudes could be the property of both the agents and the principals. The mission of the principals can thus encourage opportunistic or stewardship behaviour in the agents, depending on whether the mission is opportunistic or stewardship-like. That the agent and principal can both be either opportunistic or exhibit stewardship behaviours helps outline why the principal's opportunistic mission can encourage opportunistic acts on the part of agents and can have undesirable consequences, as discussed earlier. Hence, one can see that an opportunistic attitude in agents can be fostered by an opportunistic mission of principals. Table 2 summarises this argument.

Corporate governance systems are assumed to provide not only control and monitoring mechanisms to limit opportunistic acts of agents like shirking and stealing, but also to provide intrinsic, extrinsic, and altruistic incentives (Cardona, Lawrence, and Espejo 2003) to agents. These corporate governance systems, negotiated between principals and agents, act as moderators that condition and guide agents' behaviour. The dynamic and iterative processes in personal interaction between environmentally socialised agents and principals, negotiated corporate governance systems, and feedback from agents' behavioural outcomes back into the organisational situation within the firm may lead to path dependency and most likely generate the differences in the corporate governance systems in different locations of the world.

Table 2: Relationship between the nature of the goals/ motives of principal and agents

Principal's goals/motives (guide the setting of mission of the firm and act as agent's situational context)

\begin{tabular}{|c|c|c|c|}
\hline \multirow{3}{*}{$\begin{array}{l}\text { Agent's goals/ } \\
\text { motives (guide } \\
\text { decision to } \\
\text { participate in } \\
\text { firm) }\end{array}$} & & Opportunistic & Stewardship \\
\hline & Opportunistic & $\begin{array}{l}\text { Opportunism } \\
\text { more likely } \\
\text { reinforced }\end{array}$ & $\begin{array}{l}\text { Unstable } \\
\text { outcome }\end{array}$ \\
\hline & Stewardship & Unstable outcome & $\begin{array}{l}\text { Stewardship } \\
\text { more likely } \\
\text { reinforced }\end{array}$ \\
\hline
\end{tabular}

DISCUSSION, CONTRIBUTIONS, AND CONCLUSION

This paper presented arguments in support of a dynamic model that takes into account the nature of corporate governance systems that might help overcome the problems and limitations of the present model used in studying the phenomenon of corporate governance systems-the J/M model of agency. After discussing the limitations of the J/M model of agency and the arguments that explain the features of the dynamic model, especially that corporate governance systems should be viewed as institutions as defined by North (Menard and Shirley 2008; North 1990; North 2005), the paper presented the dynamic model. Moreover, while examining the nature of corporate governance systems, it suggested that the US sub-prime mortgage crisis of 2007 may be linked to corporate governance research and recommendations to date by means of the $\mathrm{PDH}$. Based on the arguments above, the following contributions to the literature can be identified.

First, the paper urges corporate governance scholars to use corporate governance models, like the dynamic model presented above, that take into account the fact that corporate governance systems are artificial realities in general and institutions in particular, designed and changeable by humans. The nature of artificial realities as changeable by humans implies they are subject to the $\mathrm{PDH}$, and that care in research and recommendations is needed (Ferraro et al. 2009). There is a need for a balance of abstraction, parsimony, and realism /Ghoshal and Moran 1996b) in developing theories to explain artificial realities. This is especially so if one is to avoid possible negative effects of the wrong assumptions about the audience and actors under study.

Second, the dynamic model assumes that individuals are motivated by self-interest. However, the concept of self-interest here is viewed more broadly as implying that individuals seek what they think is best for them -specifically, that individuals seek what will give them self-fulfilment and happiness. This view of self-interest (as also argued by Gomez-Mejia et al. 2005) entails that individuals can also be motivated by extrinsic, intrinsic, and altruistic incentives (Cardona et al. 2003), and not only by extrinsic incentives. The behavioural outcomes of either opportunism or stewardship of agents depend a lot on the mission of firms, the corporate governance systems put in place to guide agents' incentives and strategic decision-making, as well as the personal qualities and preferences of agents that are also reflected in the negotiated corporate governance systems. This also implies that agents who may not fit the institutions and missions of a firm may cause problems in the attainment of the mission since they may find it more difficult to work as desired. This calls for the selection of appropriate agents by principals. 
Third, the dynamic model presented above treats the firm as the level of analysis, and attempts to further the integration of the concept of institutions to corporate governance literature and research by arguing that corporate governance systems may be better understood if they are viewed as what they are-artificial realities in general and institutions in particular, designed with a purpose and changeable, depending on their effectiveness with reference to the purpose for which they were designed. Viewing corporate governance systems as institutions designed with a purpose implies that corporate governance systems are path-dependent and not necessarily economically efficient. Moreover, researchers, practitioners, and policy makers will avoid the convergence argument that all corporate governance systems are converging to the most economically efficient form, since the corporate governance system for each firm in every location may be highly context and path dependent; specifically linked to the firm's organisational field context. The paper suggests the following evaluative principle that fits well the nature of corporate governance systems as institutions.

Corporate governance systems that enable the firm to achieve its mission are effective corporate governance systems, and those that inhibit a firm in achieving its mission are ineffective corporate governance systems.

The evaluative principle above implies that third-party evaluators of corporate governance systems would need to know the mission of the ultimate decision makers of the firm in order to evaluate the effectiveness of corporate governance systems in achieving the mission.

Corporate governance systems need to be treated like other institutions in existence like syntaxes and grammatical rules of languages, dating systems, and systems of government that are not evaluated based solely on efficiency but also on whether they serve the purpose for which they were designed. To illustrate the point: Which is more efficient for tracking temporal events: the Gregorian or the Chinese dating system? Both serve the purpose for which they were designed. Therefore, each institution requires to be studied within its history and context. Moreover, by identifying corporate governance systems as institutions, corporate governance researchers can learn from other social scientists who also study institutions analytically. This enables interdisciplinary discussions.

Furthermore, viewing corporate governance systems as institutions implies that evaluating these systems without questioning the purpose for which they were designed would be erroneous. The complexity involved entails trying to analyse the contents of firms' missions, which can give clues to reasons for which corporate governance systems were designed. In addition, evaluating all corporate governance systems ex-ante based on the criteria of which system gives maximum market value for firms seems tenuous, since corporate governance systems may not be negotiated by principals and agents to get maximum market value and, moreover, market value of firms seems to not be under the control of agents and principals.

Of course, the dynamic model presented above is not without its weaknesses, especially as regards the parsimony of the model. However, it is presented as an organising and analytical framework that can be used by lecturers and facilitators in teaching about the functioning of corporate governance systems, apart from its use as a research model to guide studying and understanding corporate governance systems.

Finally, this paper ends with some normative considerations. A firm is part of broader society and has its part to play in societal wellbeing. Firms in a financial system need to align with political, social, and economic societal needs. This paper argues that nothing should be taken for granted, since firm and societal missions can be opposed, as Simon (1997:70-71) made very clear, because we are not operating in a world of an ideal market economy. The duty to make the judgment of whether firms' missions are appropriate or inappropriate seems to lie with the government as the ultimate political authority in any given society. The government may not be perfect, and its actions will vary for different political institutions in different parts of the world. Notwithstanding how imperfect the government might be, we still need to find objective and universal governing principles to evaluate means to achieve collective societal goals, and to evaluate societal values in such a way that the government makes decisions in accordance with these objective and universal governing principles and not based on the whims of the leaders.

\section{ACKNOWLEDGMENTS}

The author thanks Minna Paunova, Julia Snihur, Pascual Berrone, Domenec Mele, Joan Ricart, Africa Arino, Ebes Esho, Olusegun Olomofe, Philip Anegbe, and the AJoBE anonymous reviewers for their developmental comments on earlier drafts of this paper. An initial draft of this paper was presented at the Global Conference on Corporate Governance and the Global Financial Crisis that took place September 24-25, 2010, at Wharton School of Business, University of Pennsylvania, Philadelphia. The author thanks the conference organisers and participants for their contributions to the initial draft. All remaining errors and omissions are those of the author.

\section{REFERENCES}

Anderson, R.C. and Reeb, D.M. (2003). Founding-family ownership and firm performance: Evidence from the SandP 500. The Journal of Finance, 58, 1301-1327.

Becht, M., Bolton, P. and Röell, A. (2003). Corporate governance and control. In G.M. Constantinides, M. Harris and R.M. Stulz (Ed.), Handbook of the economics of finance, Vol. 1A: 1-109. Netherlands; North Holland: Elsevier Science Publishers B.V.

Cardona, P., Lawrence, B.S. and Espejo, A. (2003). The outcome-based 
theory of work motivation. Working paper No. D / 495. IESE Business School. Barcelona.

Dalton, D.R., Daily, C.M., Certo, S.T. and Roengpitya, R. (2003). Meta-analyses of financial performance and equity: Fusion or confusion? The Academy of Management Journal, 46, 13-26.

Dalton, D.R., Daily, C.M., Ellstrand, A.E. and Johnson, J.L. (1998). Meta-analytic reviews of board composition, leadership structure, and financial performance. Strategic Management Journal, 19, 269-290.

Dalton, D.R., Hitt, M.A., Certo, S.T. and Dalton, C.M. (2007). The fundamental agency problem and its mitigation. The Academy of Management Annals, 1, 1-64.

Davis, J.H., Schoorman, F.D. and Donaldson, L. (1997). Toward a stewardship theory of management. The Academy of Management Review, 22, 20-47.

Davis, G.F. (2005). New directions in corporate governance. Annual Review of Sociology, 31, 143-162.

Demsetz, H. and Villalonga, B. (2001). Ownership structure and corporate performance. Journal of Corporate Finance, 7, 209-233.

Dobbin, F. and Jung, J. (2010). The misapplication of Mr. Michael Jensen: How agency theory brought down the economy and why it might again. In M. Lounsbury (Ed.), Markets on trial: The economic sociology of the U.S. financial crisis: Part B, vol. 30: 29-64. United Kingdom: Emerald Group Publishing Limited.

Economist. (2009). Special report - The future of finance: Finance suffers from reverse natural selection.

Available from http://www.economist.com/specialreports/displaystory. cfm?story_id=12957761 (Accessed on March 2009).

Eisenhardt, K.M. (1989). Agency theory: An assessment and review. The Academy of Management Review, 14 (1), 57-74.

Ferraro, F., Pfeffer, J. and Sutton, R.I. (2005). Economics language and assumptions: How theories can become self-fulfilling. Academy of Management Review, 30, 8-24.

Ferraro, F., Pfeffer, J. and Sutton, R.I. (2009). How and why theories matter: A comment on Felin and Foss (2009). Organization Science, 20, 669-675. Filatotchev, I. and Boyd, B.K. (2009). Taking stock of corporate governance research while looking to the future. Corporate Governance: An International Review, 17, 257-265.

Finkelstein, S., Cannella, B. and Hambrick, D. C. (2009). Strategic leadership: Theory and research on executives, top management teams, and boards. New York: Oxford University Press.

Fligstein, N. (2002). The architecture of markets: An economic sociology of twenty-first-century capitalist societies ( $1^{\text {st }}$ paperback edition). Princeton, NJ: Princeton University Press.

Ghoshal, S. (2005). Bad management theories are destroying good management practices. The Academy of Management Learning and Education, 4, 75-91.

Ghoshal, S. and Moran, P. (1996a). Bad for practice: A critique of the transaction cost theory. Academy of Management Review, 21, 13-47.

Ghoshal, S. and Moran, P. (1996b). Theories of economic organization: The case for realism and balance (response to Williamson's response to: Bad for practice: A critique of the transaction cost theory). Academy of Management Review, 21, 58-72.

Giddens, A. (1986). The constitution of society: Outline of the theory of structuration. Berkeley, CA: University of California Press.

Gimeno, J., Folta, T.B., Cooper, A.C. and Woo, C.Y. (1997). Survival of the fittest? Entrepreneurial human capital and the persistence of underperforming firms. Administrative Science Quarterly, 42, 750-783.

Gomez-Mejia, L., Wiseman, R.M. and Dykes, B.J. (2005). Agency problems in diverse contexts: A global perspective. Journal of Management Studies, 42, 1507-1517.

Gómez-Mejía, L.R., Haynes, K.T., Núñez-Nickel, M., Jacobson, K.J.L. and Moyano-Fuentes, J. (2007). Socioemotional wealth and business risks in family-controlled firms: Evidence from Spanish olive oil mills. Administrative Science Quarterly, 52, 106-137.

Grisez, G., Boyle, J. and Finnis, J. (1987). Practical principles, moral truth, and ultimate ends. The American Journal of Jurisprudence, 32, 99-151.

Hambrick, D.C., Werder, A. and Zajac, E.J. (2008). New directions in corporate governance research. Organization Science, 19, 381-385.

Hillman, A.J. and Dalziel, T. (2003). Boards of directors and firm performance: Integrating agency and resource dependence perspectives. The Academy of Management Review, 28, 383-396.

Holmstrom, B. (2005). Pay without performance and the managerial power hypothesis: A comment. The Journal of Corporation Law, 30(summer), 702-715.

Jensen, M.C. (1983). Organization theory and methodology. The Accounting Review, 58, 319-339.

Jensen, M.C. and Meckling, W. (1976). Theory of the firm: Managerial behavior, agency costs, and capital structure. Journal of Financial Economics, 3, 305-360.

Keynes, J.M. (1964). General theory of employment, interest and money (First Harbinger Edition). New York and London: Harcourt Brace Jovanovich.

Knight, F.H. (2002). Risk, uncertainty and profit. Washington DC, USA: Beard Books Inc.

La Porta, R., Lopez-de-Silanes, F., Shleifer, A. and Vishny, R. (1999). Corporate ownership around the world. The Journal of Finance, 54, 471-517.

Lane, P.J., Cannella Jr, A.A. and Lubatkin, M.H. (1999). Ownership structure and corporate strategy: One question viewed from two different worlds. Strategic Management Journal, 20, 1077-1086.

Lazonick, W. and O'Sullivan, M. (2000). Maximizing shareholder value: A new ideology for corporate governance. Economy and Society, 29, 13-35. Levinthal, D. (1988). A survey of agency models of organizations. Journal of Economic Behavior and Organization, 9, 153-185.

Licht, A.N., Goldschmidt, C. and Schwartz, S.H. (2005). Culture, law, and corporate governance. International Review of Law and Economics, 25, 229-255.

Lubatkin, M.H. (2005). A theory of the firm only a microeconomist could love. Journal of Management Inquiry, 14, 213-216.

Lubatkin, M.H., Lane, P.J., Collin, S. and Very, P. (2007). An embeddedness framing of governance and opportunism: Towards a cross-nationally accommodating theory of agency. Journal of Organizational Behavior, 28, 43-58.

Lubatkin, M.H., Lane, P.J., Collin, S.O. and Very, P. (2005). Origins of corporate governance in the USA, Sweden and France. Organization Studies, 26, 867-888.

Mackenzie, D. (2008). An engine, not a camera: How financial models shape markets. Cambridge, MA: The MIT Press.

Melé, D. (2009a). Business ethics in action: Seeking human excellence in organizations (First edition). Hampshire, UK: Palgrave Macmillan Limited. Melé, D. (2009b). Integrating personalism into virtue-based business ethics: The personalist and the common good principles. Journal of Business Ethics, 88, 227-244.

Melé, D. (2012). Management ethics: Placing ethics at the core of good management (First edition). Hampshire, UK: Palgrave MacMillan Limited. Menard, C. and Shirley, M.M. (2008). Handbook of new institutional economics (First paperback edition). Verlag Berlin Heidelberg: Springer. Mintzberg, H. and Waters, J.A. (1985). Of strategies, deliberate and emergent. Strategic Management Journal, 6, 257-272.

North, D.C. (1990). Institutions, institutional change, and economic performance (First edition). New York: Cambridge University Press.

North, D.C. (2005). Understanding the process of economic change. Princeton, NJ: Princeton University Press.

Roberts, J. (2010). Designing incentives in organizations. Journal of Institutional Economics, 6, 125-132.

Santos, F.M. and Eisenhardt, K.M. (2005). Organizational boundaries and theories of organization. Organization Science, 16, 491-508.

Scott, W.R. and Davis, G.F. (2007). Organizations and organizing: Rational, natural, and open system perspectives. New Jersey: Pearson Prentice Hall. Selznick, P. (1984). Leadership in administration: A sociological interpretation. Berkeley, CA: University of California Press.

Shleifer, A. and Vishny, R.W. (1997). A survey of corporate governance. The Journal of Finance, 52, 737-783. 
Simon, H.A. (1991). Organizations and markets. The Journal of Economic Perspectives, 5, 25-44.

Simon, H.A. (1996). The sciences of the artificial. Cambridge, MA: MIT Press. Simon, H.A. (1997). Administrative behavior: A study of decision-making processes in administrative organizations ( $4^{\text {th }}$ edition). New York: Free Press. Summers, L. (1985). Does the stock market rationally reflect fundamental values? The Journal of Finance, 41, 591-601.

Thornton, P.H. and Ocasio, W. (2008). Institutional logics. In R. Greenwood, C. Oliver, R. Suddaby and K. Sahlin-Andersson (Eds.), The SAGE handbook of organizational institutionalism, vol. first edition: 99-129. London: Sage Publications Ltd.
Tosi, H.L., Werner, S., Katz, J.P. and Gomez-Mejia, L.R. (2000). How much does performance matter? A meta-analysis of CEO pay studies. Journal of Management, 26, 301-339.

Tricker, B. (2009). Corporate governance: Principles, policies and practices. New York: Oxford University Press.

How to cite this article: Emenalo CO. Corporate governance systems as dynamic institutions: Towards a dynamic model of corporate governance systems. Afr J Bus Ethics 2012;6:39-43.

Source of Support: Nil, Conflict of Interest: None declared

\section{AUTHOR}

Chukwunonye Obi-Ogulo Emenalo is a research associate in the Department of Accounting, Finance, and Economics of the Lagos Business School, Pan-African University, Lagos, Nigeria. His areas of specialisation are in corporate governance, corporate finance, and strategic leadership. His research base disciplines and fields include corporate finance, strategic management, new institutional economics, economic and organisational sociology, organisational studies, and moral philosophy.

\section{Author Help: Online submission of the manuscripts}

Articles can be submitted online from http://www.journalonweb.com. For online submission, the articles should be prepared in two files (first page file and article file). Images should be submitted separately.

1) First Page File:

Prepare the title page, covering letter, acknowledgement etc. using a word processor program. All information related to your identity should be included here. Use text/rtt/doc/pdf files. Do not zip the files.

2) Article File:

The main text of the article, beginning with the Abstract to References (including tables) should be in this file. Do not include any information (such as acknowledgement, your names in page headers etc.) in this file. Use text/rtf/doc/pdf files. Do not zip the files. Limit the file size to $1 \mathrm{MB}$. Do not incorporate images in the file. If file size is large, graphs can be submitted separately as images, without their being incorporated in the article file. This will reduce the size of the file.

3) Images:

Submit good quality color images. Each image should be less than 4 MB in size. The size of the image can be reduced by decreasing the actual height and width of the images (keep up to about 6 inches and up to about $1800 \times 1200$ pixels). JPEG is the most suitable file format. The image quality should be good enough to judge the scientific value of the image. For the purpose of printing, always retain a good quality, high resolution image. This high resolution image should be sent to the editorial office at the time of sending a revised article.

4) Legends:

Legends for the figures/images should be included at the end of the article file. 
Reproduced with permission of the copyright owner. Further reproduction prohibited without permission. 